\title{
GAMES OF HUNGER: THE POLITICS OF FAMINE, STATE-BUILDING PROCESSES AND CONTEMPORARY HUNGER STRIKES IN EUROPE - THE CASES OF NORTHERN IRELAND AND UKRAINE
}

\author{
JOGOS DA FOME: A POLITTICA DA FOME, OS PROCESSOS \\ DE CONSTRUÇÃO DO ESTADO E AS GREVES DE FOME \\ CONTEMPORÂNEAS NA EUROPA - OS CASOS DA IRLANDA \\ DO NORTE E DA UCRÂNIA
}

\author{
Magdalena Tendera \\ magdalena.tendera@gmail.com \\ Ph.D., Jagiellonian University \\ ORCID: https://orcid.org/0000-0003-0245-9328
}

\section{(1) (1)(2)}

Esta obra está licenciada sob uma licença Creative Commons Attribution-NonCommercial-ShareAlike 4.0 International License.

\section{RESUMO}

A fome e os períodos de fome prolongada que tiveram lugar na Europa nos últimos séculos tiveram uma dinâmica social complexa e um potencial transformador substancial que ainda influenciam a política europeia. As representações culturais dramáticas da fome tornaram-se profundamente envolvidas em várias narrações nacionalistas modernas, a fim de abrir novas fontes de lealdade política para os Estados-nação recentemente surgidos. Os períodos da Grande Fome e da Holodomor foram ao mesmo tempo momentos de uma consolidação extremamente intensa das identidades nacionais irlandesas e ucranianas e das mentalidades coletivas de múltiplas comunidades. Essas identidades chamaram a si grandes forças políticas nas periferias do Velho Continente. Assim, foram desenvolvidas algumas estratégias para transformar a experiência da fome em estratégias politicamente benéficas de resistência cívica. Essas táticas determinaram os papéis futuros tanto dos atores políticos como dos civis nos conflitos de soberania. Utilizando uma abordagem comparativa, este artigo explora a forma como os processos de construção do Estado na Ucrânia e Irlanda do Norte nos séculos XX e XXI foram enquadrados pela fome, o aumento da sociedade civil, greves de fome, e como a escassez de alimentos se transformou no caráter das nações. Tal mentalidade transformou-se num sério impulso para que alguns projetos políticos na Ucrânia e Irlanda se tornassem Estados-nação modernos e integrados em sociedades europeias cada vez mais globalizadas. As narrações culturais convincentes e arrebatadoras sobre a fome são profundamente atuais e políticas, bem como fenômenos europeus, e como tal devem ser analisadas através da lente 
conceitual da modernidade e pós-modernidade, e das formas internacionais de coesão política e econômica.

Palavras-chave: teorias da fome; fome na Europa; movimentos nacionalistas; sociedade moderna; greves de fome.

\section{ABSTRACT}

Starvation and periods of prolonged hunger that took place in Europe in the last centuries had complex social dynamics and substantial transformative potential that still influence European politics. Dramatic cultural representations of hunger and starvation became deeply engaged in various modern nationalist narratives in order to open new sources of political legitimacy for newly arising nation-states. The periods of the Great Famine and Holodomor were, at the same time, moments of an extremely intense consolidation of Irish and Ukrainian national identities and the collective mindsets of multiple communities. Those identities became major political forces on the peripheries of the Old Continent. Hence, some strategies of transforming the experience of hunger into politically beneficial strategies of civic resistance were developed. Those tactics determined the future roles of both political and civil actors in sovereignty conflicts. Using a comparative approach, this paper explores how the state-building processes in Ukraine and Northern Ireland in the $20^{\text {th }}$ and $21^{\text {st }}$ centuries were framed by hunger, the raise of civic society, hunger strikes, and how the mindset of food scarcity grew into the characters of these nations. The mindset has turned into a serious drive for some political projects in Ukraine and Ireland to become modern nation-states integrated with increasingly globalized European societies. The compelling and enchanting cultural narratives on hunger are profoundly up-to-date and political, as well as European phenomena, and as such should be analyzed - through the conceptual lens of modernity and postmodernity, and the international forms of political and economic coercion.

Keywords: theories of famine; hunger in Europe; nationalist movements; modern society; hunger strikes.

\section{INTRODUCTION}

Large-scale hunger, famines, and temporary food shortages, that the modern world has witnessed in the last two hundred years, are mostly the acknowledged outcomes of contemporary political and cultural conflicts across the globe (CRIBB, 2019; BUTTERLY; SHEPHERD, 2010; BNE SAAD, 2013). Such conflicts cause multiple failures of food-supply systems capable of affecting every country in the world. Even the wealthiest ones in the Western world can face food-scarcity issues as a 
result of dissension with major economic partners or violent internal systemic transformations (CAVALCANI, 2005).

In this essay, I am going to investigate a different aspect of these problems, namely the political impact of famine and hunger as a cultural legacy, a mode of individual and collective experience, and especially the way hunger evolved into hunger strikes to become a distinct form of political agency for endeavors of achieving independent modern statehood status. I will discuss the main circumstances in which the past famines and processes of political separation in Northern Ireland and Ukraine brought to life the contemporary ethos of hunger strikes and established the importance of hunger symbolism for conflicts around borders and state sovereignty, and, finally, reinforced anticolonial and nationalist movements. The way that those events are remembered and reproduced in Irish and Ukrainian oral history remains a critical framework in understanding the contemporary political processes in Europe (NOACK; JANSSEN; COMERFORD, 2013). The investigation relies on the secondary analysis of existing sources.

Large-scale hunger and famines, witnessed nowadays by the postmodern world, are mostly a result of contemporary global political and cultural conflicts. The body of recent work on hunger and famines concentrates on preventing the potentially harmful physical outcomes of extreme malnutrition in the most impacted regions in the world, and devises the most effective solutions to support the most vulnerable populations (e.g., Rise Against Hunger, the United Nation's World Food Programme or the Food and Agriculture Organization). Hunger also impairs social and cultural aspects of all the impacted regions - in Africa or Europe - and their processes of repairing cultures, social bonds, and trust in institutions outlive generations. Therefore, managing the available aid solutions to support the most vulnerable populations is an issue of high complexity, and long and short-term local and international policies (UNICEF, 2006).

Some similar historical conditions in Ukraine and Ireland made it possible for famine to cause the birth of a hunger mindset that has subsequently turned into a relatively successful political strategy - not solely a method of resistance, but a tactic of open confrontation in situations of political stalemate. Unexpectedly, the paradox of "the more food, the more hunger" radicalizes when, for the first time in human history, there is enough food for everyone. Especially in Europe, widespread democratic systems backing NGOs and humanitarian aid, promoted by the Universal Declaration of Human Rights, secure its equal distribution. Yet, this is also the time when "the number of global hungry started accelerating: from the baseline of 781 million in 1989 to 915 million by 2008, crossing the mark of 1 billion for the first time in 2010 " (BUTTERLY; SHEPHERD, 2010, p. 17).

Food has become an object of systematic global planning and a commodity of broad international exchange on quickly multiplying markets 
of all types and geographic extensions. Modernity had a precedent in this regard, as the amount, scale, and scope had never before been as large. Hence, only a modernistic and postmodern conceptual frame appears to be useful in a more thorough investigation of the food paradox. Since the political changes analyzed in this study extend over at least two hundred years, post-modernity is here understood in very general terms - simply as an intensification of all the social, economic and political processes launched in the modern era.

The political importance of hunger can be analyzed concerning the geopolitical dimensions of the Old Continent, especially in those regions that occupy a "permanently transitional" position, located at its peripheries. Those regions are the most likely to experience severe disruption in the food system. In Europe, the experience of famines and the imaginations of hunger fill important positions among various cultural symbols of the borderlands. However, this is also true for less-known cases of famine, for instance, those that have appeared in Germany or Great Britain during World War I. As Cribb notices: "as for the future of humanity, the larger significance of World War I was the formal weaponization of food" (CRIBB, 2019, p. 49).

As an extension to this process, hunger has grown into some of the collective mindsets of peoples from those new geopolitical formations (states, regions, etc.) that simultaneously struggled with food scarcity and political or military conflicts. The artifacts of Hunger (monuments, graves and graveyards, oral history, scarcity mindset, social codices and ideologies of violence, murals and other forms of art, etc.) are living proof of the potential for the hunger experience to interfere with the contemporary, postmodern European societies and their mentalities, imaginations, and attitudes.

The modern food policies in the European Union attempt to consider a whole range of factors that can potentially disrupt the food systems in all the EU countries: "a food and nutrition policy will thus have to address issues beyond traditional health interests and include agriculture and fisheries, the environment, rural development, food manufacture, and foreign trade. It may selectively apply policy instruments such as economic subsidies and taxes, regulation of food standards, labeling and advertising, provision of direct services (such as nutrition counseling, meals-on-wheels, and mass catering), training and education of personnel and the public, and research on and evaluation of consumer and organizational behavior" (MILIO, 1998, p. 12).

\section{NATION-STATE AND TERRITORY IN MODERNITY}

Besides the hunger mindset, two other features shall be considered as indicators of when a modern European country (e.g., Northern Ireland or Ukraine) is fighting for independence: the level of stability of its political borders (and whether they can be easily challenged and by whom), 
and the scope to which sovereignty extends over all the formal institutions in the country - or, in short, political autonomy. The importance of both issues in Europe meant that "for much of the twentieth century, borders and state sovereignty were depoliticized in the sense that they were not up for debate. It was taken for granted that humans lived in states, those states contained nations, and those nations should be the fundamental political units" (JONES, 2016, p. 179-180). However, some assumptions on the sovereignty of borders, in particular European regions, are that they have regularly been called into question by deliberate political actions that involve violence. The process is not close to being fulfilled, remaining unpredictable and hard to tame and quantify.

But there is a more complex power than local revolutionary movements - modernity is also a period when "the autonomy of the nation-state is called into question not only by the meta-power of global business actors but also by that of global civil society. Its meta-power is based on establishing the validity of human rights in opposition to the nation-state-based apparent "taken for grantedness", according to which states can do whatever they please within their sphere of domination. The politics of human rights also opens up an arsenal of strategies for silently revolutionizing the international system" (BECK, 2005, p. 64).

\section{HUNGER IN MODERN TIMES: TOWARDS POSTMODERNITY AND TRANS-NATIONAL ECONOMY}

The first and most important Millennium Development Goals set by the United Nations in 2000 was to "eradicate extreme poverty and hunger" ${ }^{\prime}$ as a serious threat to world security and development processes (PRONK, 2015). The Nobel Peace Prize 2020 was awarded to the World Food Programme for combating hunger in the areas affected by conflict, "and for acting as a driving force in efforts to prevent the use of hunger as a weapon of war and conflict" 2 . The UN estimates that hunger will double in 2020 to 265 million people ${ }^{3}$.

The traditional approach to famine favors understanding hunger in terms of lack of food caused by drought, flood, or other natural disasters that appear mostly locally, and are highly unpredictable if not connected to the changing of seasons. This traditional approach is characterized by the parochial scope of the explanation: a nation or community is starving because the local crops were destroyed by drought. In the global economy, the mechanisms of food distribution are fairly different, with tools such as planning and separate institutions responsible for food security, a high level of predictability, and an increase in the general security of the chain of food distribution. From the $18^{\text {th }}$ century on, we have witnessed accelerating globalization that subsequently enforced the birth of totally new networks of food supply: dense, effective, and politically-governed. 
How, then, in such a late-modern conceptual frame, can a single, hungry, bare life become a political value capable of challenging a given political status quo? How can a hunger strike in social seclusion become such a powerful political instrument? As far back as early modernity, life started to be the major concern of political power across Europe. A new political mode, the biopolitical paradigm, revealed "the question of a particular juncture between two terms: power and life, which requires that both be redefined. This question of biopower, this juncture of life and power, constitutes a part of a multidirectional and nonunified history of political techniques or the art of governing, the stakes of which are life" (GENEL, 2006, p. 44). "Who governs a life?" is the question of political agency and the way it can be attained: through the limits and potentialities of the agency.

The particular historical context of modernity, newly emerging relations of power, and local conditions need to be described and investigated to discover how strong the connotation between state politics, hunger, and resistance is in some peripheral European regions, and how they still resonate in the postmodern world as a form of biopolitics: a specific, local and temporary relationship between politics and life in those regions where famine was not just an outcome of food shortage, but it was entwined with dozens of social, historical, cultural and political processes, and mainly those of domination: "however generalized it may become, biopolitics is not itself a universal phenomenon (...) A logic of formation is therefore historical, local and particular" (DILLON; LOBO-GUERRERO, 2008, p. 267).

\section{THE POSTMODERN THEORY OF FAMINE}

Famine is defined as an extreme and protracted shortage of food, having consequences in death rates and diseases in an affected population (see: BUTTERLY; SHEPHERD, 2010). What differs post-modernity from modern times is the emphasis on the cause of famine, the question of its perpetuators, and the intentions and aid potentially available and yet, for some, not provided.

The postmodern theory of famine is more a trend, or approach, than a single theory. It is characterized by the "new famine thinking", which regards famine solely as the failure of accountability. The politicization of famine is in its focus, as Bne Saad writes: "famines are related to political regimes. Most twentieth-century famines occurred under authoritarian, unaccountable regimes, colonial administrations, military dictatorship, and one-party states, or during wartime" (BNE SAAD, 2013, p. 61 ). The connection between famine and conflict is a complex issue, yet wars always disturb the food system. The accelerating globalization of the factors creating famines (exercising economic and political power), and finally, the role of the global humanitarian industry, which plays a considerable role in decreasing famine deaths (BNE SAAD, 2013). 
This clearly shows that the postmodern context does not differ radically from the modern one: "signs and tokens of radical changes in labor processes, in consumer habits, in geographical and geopolitical configurations, in-state powers and practices, and the like, abound. Yet we still live, in the West, in a society where production for profit remains the basic organizing principle of economic life. We need some way, therefore, to represent all the shifting [...] which does not lose sight of the fact that the basic rules of a capitalist mode of production continue to operate as invariant shaping forces in historical-geographical development" (HARVEY, 1989, p. 121).

The capitalist mode of production for profit in postmodernity remains dominant. Thus, how hunger can be politicized, and food politics may be explained as part of the mechanisms to control other populations or social groups: "according to Foucault, it is the various differences, including status, economic standing, and gender in a given social group that enable some members of the group to act upon or structure the actions of members of that group. Acting upon the actions of others, though, also serves to (re)create social categories that lead to social differentiation [...] This is a critical point for food security studies, since it suggests that social differences are not, a priori, categories with specific characteristics we can deploy to explore a particular context (a mode that dominates the current social debate of food security analysis). Instead, they are constantly under construction as they are put into practice" (CARR, 2006, p. 20).

Mass starvation is seen as a form of modern warfare used systematically across the world, yet it is still difficult to prosecute. Thanks to global industrial chains that can be disturbed in multiple ways, "today's famines are neither random nor accidental 'costs of war' but intentional atrocities and lawyers and scholars are making a case to punish starvation at

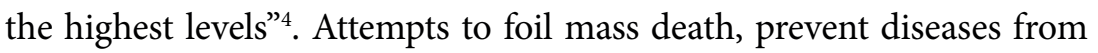
spreading and stop crimes against humanity along with famines need a better-developed legislative framework that will allow for prosecution.

\section{HISTORY OF THE CULTURAL CONFLICT - NORTHERN IRELAND AND UKRAINE}

Hunger is simultaneously a direct and indirect result of conflict: "people who die in wars perish from hunger, as their food stocks are plundered and devoured by marauding armies, farming is disrupted by military recruitment, food requisitions and scorched earth policies, and the food and trading systems that sustain their society collapse. Contrary to the popular imagery of war, hunger is a far greater killer than military action or diseases, though it interacts with both" (CRIBB, 2019, p. 1).

The conflict background multiplies the degree and magnitude with which hunger marks a society, especially during its transformative years: "cultural conflicts, accompanied or sharpened by economic inequalities, 
outlive generations. They are less manageable than economic conflicts because there is no way out by means of sharing or redistribution [...] Cultural conflicts are different. Identities are defined in terms of the absolute position of one group in society [...] [which] always means that another group will lose. Welfare is a relative concept; it can be increased through intelligent distribution. Power is an absolute concept; total power cannot be increased by means of redistribution. Only when cultural conflicts are not seen as conflicts of power, but as conflicts of identity can a solution be possible, provided that each group considers its identity not threatened but enriched through interaction with each other. Cultural confrontation has to be transformed into a cultural exchange" (PRONK, 2005, p. 77-78).

How the relationship between hunger and modes of power exertion has developed can be investigated using the case of hunger strikes in Northern Ireland and Ukraine. The case of Irish hunger strikes in the Maze Prison, in Belfast, during the 1980s, was dramatic, yet one of many in Irish history. Adopting a hunger strike as a tool in political conflict in Ireland has its roots in ancient times and gained popularity after the age of the Great Famine (1845-1849). Famine is considered a natural disaster, as well as a political affair between Ireland and Great Britain that turned into a tool of extermination for political purposes. 5 . The Great Famine was caused by late blight, yet a proper food policy of the British authorities could have prevented the negative outcomes. A lot of research proves "a shocking combination of ambivalence, incompetence, and malignance on the part of British policymakers"'.

The British policy toward Ireland was deliberately inconsistent: "English warfare employed a razed-earth policy to 'break the hearts' of those who resisted, and the result was a collapse of the local population through famine" (MULHOLLAND, 2002, p. 2). The strategy of hunger-striking was already common during the Irish Revolution (19191921). The hunger strikes of 1917 and the death of Thomas Ashe as a result of force-feeding are well-known historical facts concerning the behavior of Irish soldiers, nationalists, politicians, and volunteers. In the 1980s, when the escalation of Irish-British conflict around the border and the independence of the Irish state escalated, Bobby Sands became the first of ten prisoners to die of starvation. A Provisional Irish Republican Army (PIRA) volunteer, who was fighting for the political status of war prisoner just before his death in 1981, he was nominated and successfully elected as an MP to the House of Commons. During this protest, ten prisoners, all Irish Republican Army members, lost their lives.

Hunger strikes were a thoughtful and deliberate strategy. For the socalled "second hunger strike" in Maze Prison in 1981, an intricate plan of action was designed and implemented: "Bobby Sands would be the first to begin refusing food and he, Bic McFarlane and the outside leadership were involved in selecting those who would immediately follow 
him. This time their strategy would be different. The PIRA had learned lessons from the first hunger strike about the weakness of collective decision-making. On this occasion one prisoner at a time would start refusing food with a sufficient gap between prisoners, so doing to ensure that it ran its course. This would eventually create a situation of almost continuous crisis for the Government, as the condition of hunger-strikers deteriorated, or they died. The strategy was also based on the psychological assumption that one prisoner on his own, unconcerned by the situation of others, would be more inclined to go through to the death" (MURTAGH, 2018, p. 379).

All were given the status of national and religious martyrs; their deaths were causing riots on the streets against the British colonial forces. $* * *$

On the other side of Europe, the $20^{\text {th }}$ century witnessed a corresponding case of modern European famine: the Holodomor (1932-1933), which is also called the Ukrainian Genocide, has caused the death of roughly seven million Ukrainians. The Holodomor was a period of extreme famine caused by a human factor - namely policies designed by Stalin towards the Ukrainian part of the USSR. There are numerous interpretations of what happened: "there are several schools of thought as to the motivation behind the Great Famine. In Ukraine, it is still viewed as a purposeful act of genocide on the part of ethnic Russian communists against Ukrainians" (CRIBB, 2019, p. 39). However, the interpretation of a deliberate and conscious action of extermination is the dominant one (APPLEBAUM, 2017).

The hunger plot appears to be the key element of revolutionary politics and still has a vital political resonance. Holodomor, along with the Great Famine in Ireland, has contributed to the creation of a cult of hunger that attempts to make such death, or - to be more precise - a dying process, a politically significant event. The case of the hunger strike by Oleg Sentsov in a Russian prison shows some of the mechanics behind the action ${ }^{7}$. The Ukrainian film director starved for 145 days ${ }^{8}$ against the injustice of his detention and of others, which led to his being recommended by the former Polish President Lech Walesa for the Nobel Peace Prize 9 . In the meantime, he was also nominated for the Andrei Sakharov Prize for Freedom of Thought. These nominations were not only a way of keeping him in the mainstream political orbit and giving him the chance to save his life and health but also - as was the case with Bobby Sands - a way of giving him and the protest an additional and extraordinary political status. This newly achieved social position, a high political rank of importance legitimated by the hunger strike, cannot be easily ignored by anyone. In Ukraine, before Oleg Sentsov, Yulia Tymoshenko $^{10}$ (a former prime minister of Ukraine) launched a hunger strike in prison. A few years ago, Nadia Savchenko ${ }^{11}$ adopted a similar strategy. These events were followed by others, for instance, Volodymyr Balukh ${ }^{12}$. 
There are other cases of contemporary Ukrainian hunger strikes, such as the one by the opposition politician, and former Georgian President, Mikheil Saakashvili. ${ }^{13}$ The former Ukrainian Interior Minister Yuriy Lutsenko ${ }^{14}$ started a hunger strike, which Tymoshenko urged him to end ${ }^{15}$. A significant number of Ukrainian prisoners in Russian prisons ${ }^{16}$ and citizens outside them ${ }^{17}$ have declared hunger strikes for various political reasons. In Ukraine, in 1990, "a core group of 200 students participated directly in the hunger strike, while many others joined to participate in the general strike over the next several days, increasing support to thousands of people. Opposition members of Parliament also joined, and solidarity made the group amount to about 15,000 people. Students were inspired by the demonstrations in Tiananmen Square, and adopted similar tactics, namely nonviolent techniques of hunger strike and occupation" ${ }^{18}$. According to Christine Emeran, it can be argued that student hunger strikes, along with those taken up by political persons, are a part of a new generation of political activism in Ukraine (EMERAN, 2017)

In the years of famine, a new national identity was consolidated by political moments. The Irish Famine and Holodomor created a turning point between how the nations saw themselves before and after. Afterward, the ethos of the hunger strikes merged with the national one.

Some thinkers argue that only a strong and legitimate personal identity with a nation-state guarantees the applicability of human rights, so precious when part of political resistance. Agamben states that human rights, in practice, work similarly to citizenship rights and privileges, but definitely not parallelly to universal norms, although they were intended to do so (AGAMBEN, 1998). "In the system of the nation-state, the so-called sacred and inalienable rights of man show themselves to lack every protection and reality at the moment in which they can no longer take the form of rights belonging to citizens of a state" (AGAMBEN, 1998, p. 126).

One can argue then that the reverse process took place during the hunger strikes in British and Russian prisons: when a political rank and a special category of national status (e.g., war prisoner) constituted the object of the struggle for the Irish and Ukrainian citizens that went into starvation, it became the game-changing factor. This strategy has to do with advocating for their state as well as their identification as citizens, and promoters of the national ethos and a tremendous and exquisitely strong national attitude. Thus, "if the only method of acquiring rights is through the assertion of nationality, then the likelihood is that when a majority and minority culture clash with a state each will claim sovereignty and self-determination on the basis of its nationality" (GIRIVIN, 1998, p. 370). Nationalism played a crucial role in the process of state-building since it "can provide one of the strongest sources for po- 
litical legitimacy but it may be the main source of instability if national identity or sovereignty are in dispute" (GIRIVIN, 1998, p. 369). However, not only the Ukrainian and Irish people use nationalistic ideologies. British and Russian nationalism has also played important roles: "the nationalistic attitude is present among both sides of the conflicts, yet is expressed in different ways. The reality is quite plain: the 'end of the era of nationalism', so long prophesied, is not remotely in sight. Indeed, nation-ness is the most universally legitimate value in the political life of our time" (ANDERSON, 1983, p. 3).

A lot of such nationalist-driven actions are being suppressed. The criminalization ${ }^{19}$ of Ukrainian sailors versus the process of criminalization of the IRA volunteers and denial of the POW status in Russian and British prisons reveals the dialectic and discursive dimension between the power of the official authorities and the agents of resistance and separation. In Ireland ${ }^{20}$ : "historically the issue of republican prisoners has assumed a central place in the republican position and message, particularly in relation to the struggle for recognition and legitimacy which culminated in the Hunger Strikes of the early 1980s. When Northern Ireland secretary, Merlyn Rees, ended special category status in March 1976 a bitter battle ensued between the H-Block prisoners and the British Government. Margaret Thatcher's policies of criminalization resulted in H-Block prisoners embarking on a Blanket Protest in 1976, which led on to Hunger Strikes in 1980 and 1981" (MCGLINCHEY, 2019, p. 54). Being presented as soldiers or criminals, their task is to push their credibility beyond any doubt and prove their sanity and personal agency to the world.

Obviously, the struggle for the status of POWs and recognition of personal agency during imprisonment is supported by some specific narratives. Those narratives explain the intentions behind the sacrifice: "if suicides are induced by despair at circumstances entirely beyond the prisoners' control, then they are merely consequences of the agency of others and, in this case, an expression of little more than the limits of what the $[\ldots]$ men were able to bear. The dilemma for the prisoners, then, is that sympathy at their plight divested them of agency and thus occluded what might otherwise be read as the exercise of an oppositional politics" (BEIER; MUTIMER, 2014, p. 316). It is common in case of suicide in prison that: "the deaths were placed within two competing narratives, one of madness and one of despair [...] Both of these narratives, however, deny the prisoners access to political agency" (BEIER; MUTIMER, 2014, p. 315). In the situations when prisoners commit suicide the reasons and circumstances testify to their level of agency.

Apparently, the narrative of deliberate starvation as a sign of personal control and political agency is immanently inscribed in the modern Irish and Ukrainian strategy of political resistance. Thanks to the history of the famine, Irish predecessors leading revolutionary movements whilst on hunger strikes, and cultural processes that have merged all 
these things together, the hunger strike became a legitimate and culturally accredited practice in Ireland and Ukraine. Similarly, the Ukrainian society, having experienced famine and organizing hunger strikes in the 1990s, has encoded a particular instruction of behavior that was demonstrated by the Ukrainian politicians at the top. Hunger then is never a private matter, and a hunger strike is like telling a story, "a strategy for transforming private into public meanings [...] seeing storytelling as a vital human strategy for sustaining a sense of agency in the face of disempowering circumstances" (JACKSON, 2013, p. 34). Thanks to the ethos and meanings encoded in hunger strikes, even if this storytelling is done by means of short public communications than in complex narratives, it maintains its basic political function.

Citizenship and nationality of a state in the very process of making and the liminal aspect of hunger strikes are about to morph the hunger and the impact it makes it into a more accomplished form of political agency in terms of cultural legality and personal agency.

The abovementioned similarities are not the only common aspects, and there are some other significant similarities between the political situation in Northern Ireland and Ukraine. Those already known include a kind of semi-colonial status of both countries and the involvement in a permanent potential of military conflict (the border in Ireland, the current war in Donbas, and the previous annexation of Crimea by Russia), all within a general political landscape of the Old Continent and a distinctively European social, cultural and economic reality, that promotes the values of freedom and democracy.

\section{POLITICS ON AN EMPTY STOMACH: STATE-BUILDING PROCESSES IN NORTHERN IRELAND AND UKRAINE}

The feud between Unionists and Republicans in Northern Ireland is considered to have been officially solved by the Good Friday Agreement, signed on April 10 $10^{\text {th }}, 1998$. Yet, the incomplete decommissions of weapons (estimations say about $80 \%$ has been achieved) and a high level of crime in the region are indicators that the ethnic-nationalist conflict is enduring: "the central political dynamic in Northern Ireland remains a fundamental conflict over national identity between ethno-sectarian groups competing over territory and resources. A system of relationships was established in the seventeenth century that created antagonisms between Ireland and Britain and within Ireland, based on ethnicity, religion, and culture that have proved to be very persistent. The conflicts of interest have continued to feed a strong process of ethnic and cultural formation based on opposition to, and difference from, the other group" (ACHESON; MILOFSKY; STRINGER, 2014, p. 21).

When some temporary administrative solutions became durable, they can have damaging consequences: "the Troubles have produced a ratchet shift in attitudes, and much 'emergency' legislation is likely to be 
made a permanent feature of the legislative framework of society" (MULHOLLAND, 2002, p. 27), making Northern Ireland a state in constant alert. When nationalists understood that Northern Ireland under British rule may not be just a temporary phase, it caused massive civil disobedience. Full consolidation of a new state did not happen. To some extent, "it was a coincidence of conquest with a religious schism that prevented the emergence of a nation-state uniting all classes" (MULHOLLAND, 2002, p. 29). Unionists had to admit that "Catholics had to be prevented from insinuating themselves into the apparatus of the state. Their loyalty would never be anything more than conditional, temporary, and probably insincere. Over one-third of the population was to be regarded as a permanent threat" (MULHOLLAND, 2002, p. 29).

This case of nationalist endeavors in Ireland, specifically, appeared to be more significant for the realm of peace politics than a concept of a united society, as nationalism - not only in Ireland but also in Ukraine "provides a sense of political identity and emotional satisfaction for the vast majority of people which no other political value does. Moreover, with its emphasis on community, territory, and sovereignty, nationalism offers a source of moral superiority to its members, expressed through patriotism" (GIRIVIN, 1998, p. 370).

The contemporary relations between Ukraine and Russia are of similarly complex genealogy. The colonial dimension is a major historical factor influencing the emergence of a particular Ukrainian culture of political resistance. The collapse of the Soviet Union and the transition of Ukraine into an independent state could yet turn into an ethnic conflict. Ukraine, as a new nation-state, had to come to terms with such issues as what its population is in terms of its ethnic composition, official history, and common culture, regions, law, and cultural elites. Forming a national identity is a process. For example, is Ukraine a mono or multi-ethnic state? There are some serious obstacles to that, and they can be characterized as follows: firstly, the Russian-speaking Ukrainians prove that national identity does not always arise from language. Secondly, there is strong ethnic criticism, by Ukrainians, of the moderate nationality policies undertaken in both the Kravchuk and Kuchma eras and the desire to see Ukraine become more "Ukrainian". Finally, there are some of the Ukrainian neighbors, in particular Russia, which have threatened military intervention in defense of "Russian speakers" (KUZIO, 1998, p. 127). All these circumstances make the situation even more politically complex and complicated.

It is the conflict between multidimensional identity versus the one nation-state idea that regularly haunts Ukraine: "nation-building, if based exclusively upon ethnic criteria, would lead to domestic conflict; it is anyway supported by only a tiny radical right-wing fringe and unlikely to become government policy. Overall, there is sufficient consen- 
sus among most Ukrainian political groups that Ukraine will comprise both civic and ethnic elements in its nation-building project" (KUZIO, 1998, p. 134). Concerning regional diversity in Ukraine, its regions have different histories and cannot be easily merged into one narrative, which exists alongside the question of resources and energy supplies (e.g., Ukraine depends on Russian gas, which is transmitted through the country to Central Europe) and the political position of Ukraine as a thorn between Russia and NATO (see KAPPELER, 2014).

These modern European political conflicts have many common dimensions, but their advocates are also broadly criticized. The major aspect of the critique are forms of legitimization of the national projects that stand behind them. Concerning the critique of the republican project of state-building: "the Provisionals continually faced this contradiction, which became salient during the Hunger Strike campaign in the early 1980s, amid conditions that allowed the republican movement to take the historic step toward electoral politics, but which also amplified the problems of waging an increasingly brutal war while striving for popular support" 21 . It is a consensus that "a variety of much wider factors contributed to the republican peace process, including widespread war-weariness after almost three decades of conflict and a more general recognition that armed struggle was incapable of winning ${ }^{22}$.

A critique of the Ukrainian project of national politics promoted along the hunger strikes points out that it seems to be extremely elitist and not radical enough. The contemporary Ukrainian hunger strikes are seen more in terms of public performance being designed for media display. They do not lead to death and are undertaken mostly by major Ukrainian political and public figures to draw international media attention, rather than directly confront the Russian system of repression.

Additionally, the referendums held in Northern Ireland (1973 and 1998) show that there is not enough support for the separatist ideologies in the region under consideration, and the question of the legality and legitimacy of those voting campaigns were at different stages and from positions called into question. Finally, the referendums and multiple surveys conducted on the issue of Northern Irish and Crimean (2014) independence show that, in fact, the social divisions remain substantial in terms of support for all the potential scenarios.

The very fact that the nationalist movements and their narratives are resonant with the societies does not indicate that the other accounts do not play vital roles in Ukrainian and Irish political discourses, or that peace, stability, and the economy may not be strong enough arguments against separation. The state-building processes are partly designed to achieve and allow a compromise in the previously unmanageable conflicts to avoid more bloodshed that seems to be inseparable from violence, which is unenviable if conflict sparks again. 


\section{BORDERS AS A PIVOTAL QUESTION FOR STATE SOVEREIGNTY}

There are numerous theories of borders that may clarify the very nature of the cultural conflict. Some thinkers have later offered a concept of frontiers that divides them into good or bad, and that typology is based on a distinction between good and bad borders. This distinction is related to their defensive character and stability (SCOTT, 2013). This basic and simple division appears useful in understanding the difference between Russo-Ukraine's and Northern Ireland's border with the Republic: it is their instability and defensive character. Moreover, they also often refer to some significant territorial losses that took place at some point in the past (SCOTT, 2013). Thus, "the starting point for our analysis is that cross-border initiatives connected to building peace are premised on two core assumptions: (1) that the border is a root cause of conflict because it embodies cultural difference and alienation, and (2) that border is a consequence of conflict because it embodies the harm of conflict" (HAYWARD; MCCALL; DAMKAT, 2014, p. 192);

For ethnic and historical reasons, the northern part of the Russo-Ukrainian border is more stable than the southern part (see KOLOSSOV, 2011, p. 177), so each of the borders of each country is not an homogenic construct. Additionally, some aspects of the geopolitical dimensions of borders are important for developing the perspective of the occurrence of famine:

- borders make all the major political processes possible, but the bordering regions also have their specifications: "the Crimea and the Donbas are Ukraine's only two regions which are likely to remain problematical in terms of nation-building. Although separatism as a mass movement collapsed by 1995 , the potential will remain for the Crimea to also remain a threat to Ukraine's state territorial integrity. This is especially the case in view of the fact that three-quarters of Russian opinion believes that the Crimea and Sevastopol should be rightfully under Russian sovereignty. In the Donbas though, contrary to the view of many outside observers, separatism never became a mass movement and is unlikely to do so in the future" (KUZIO, 1998, p. 82).

- modern borders can make a closure: Holodomor was feasible only because Stalin could close the borders of the Ukrainian part of the USSR; before Holodomor took place, a border was built around the Ukrainian part of the USRR to separate it from the rest of the country. Moreover, "the current Russian leadership in fact doesn't recognize Ukraine's sovereignty, territorial integrity, or the inviolability of its borders (especially with Russia). It makes these conditional on Ukraine's participation in Russia's self-perceived sphere of influence. Moreover, Ukraine's 
case should be interpreted more broadly as applied by Russia to the whole post-Soviet area. One may also interpret the intentional ambiguity of certain major Russian policy statements as going beyond that area, although probably limited to the historical-geographical area of the Russian Empire" (MENKISZAK, 2015, p. 84).

Some Russian reasonings and the discourse on how sovereignty is undermined by border aggression can be investigated through competing narratives on Ukrainian identity, "the recreation of an outdated notion (non-existent in modern Ukrainian or Russian political discourse, except for some marginal Russian nationalistic groups) of Novorossiya by the Russian state propaganda and officials suggested it had become a political project of the Kremlin used for justifying the political autonomy of the southeastern part of Ukraine or even its future secession and joining Russia. What was clear though is that it directly undermines Ukraine's territorial integrity and borders" (MENKISZAK, 2015, p. 93).

There is an entire debate in the EU on the issue of the Ukrainian border and thus Russia has met some consequences in economic and diplomatic terms, and there are a lot of myths and misunderstandings in how to read the Russian border politics. Also, "taking into consideration both rhetoric and policy actions in the course of the last several years we may conclude that from Moscow's perspective its borders with the post-Soviet states are not considered as fixed and inviolable. Their recognition by Moscow, as well as the recognition of territorial integrity and formal sovereignty of Russia's post-Soviet neighbors, is in fact conditional. The main condition is that neighboring states should pursue a friendly policy towards Russia and refrain from actions which may be perceived in Moscow as detrimental to Russia’s self-perceived national interests" (MENKISZAK, 2015, p. 101). The following is the result of this.

\section{THE CONFLICT MINDSET}

The major political consignment of hunger representation in modernity is the cultural legitimization of some social strategies of resistance supporting separatist movements and some among state-building processes. They also reverse miserable and damaging experiences and can enhance their hugely appalling and transformative political potential. Famines and hunger practices enhance and legitimize various social strategies of resistance, national struggle, or even military conflict. These strategies have evolved throughout history and up until the $21^{\text {st }}$ century, when they have been able to shake the very core of Western culture as a reminder of how powerful the social experience of hunger and famines is, and what comes after: a powerful collective mindset.

There is another more "discursive" dimension: the political consequences of these events, some of which may be of seminal importance for the shape of the future European project, impacting on the border 
security and stability of European external frontiers, inspiring new movements for independence or re-igniting old folds, and augmenting military conflicts and threats of terrorism on the peripheries of the mainstream of European politics.

The Irish border between Northern Ireland and the Irish Republic is crucial for the integrity project of the European Union and the peace process in Ireland and Ukraine. The Good Friday Agreement is the backbone of the entire international mission; however, it is also hard to escape the fact that the Northern Irish state has an inseparable relationship with paramilitaries; is sustained by the dialectic between sectarian divisions and violence, and social projects designed to maintain the fragile peace and support the economy. The profound divisions in access to education, job market, and housing policies remain a bone of contention.

\section{CONCLUSION}

As demonstrated above, famine significantly shapes national politics and ethos: the nation-state, nationalism, borders, social movements, and freedom movements, strategies of social resistance, are just some of the elements inspired by hunger.

Some questions still need elaborating: how can the relationship between power and life as the core of the relation between politics and life, in 20th and 21st century Europe, be described? Is this relationship particularly specific in Northern Ireland and Ukraine when analyzed through the lens of extreme hunger experience? How did death by starvation become a deliberate strategy of bargaining over the price of a bare life and giving it a special, political status, finally merging sacrifice with state sovereignty and independence?

Furthermore, what is fascinating is the relationship between hunger and the borders as a geopolitical delimitation of the hunger symbolism - a border is the place where the politics of liberation turns into practice, conflicts violently escalate, and prisons happen - where the conflicts shift and gain a new political dimension. Instability in both countries is expected for years to come as an effect of Brexit and the ongoing British-Irish conflict, and the constant feud in Ukraine on the state sovereignty with Russia, bringing the discussion on hunger strikes back to the agenda of international debate. Finally, the relationship between Ukraine and Russia, as well as between Northern Ireland and Great Britain, is a profoundly European issue as it sends us back to the very nature of borders, economy, identity, and the political importance of hunger. Finally, all the comments and interpretations included in the study may change or lose their importance as new historical facts can be discovered or new paradigms and solutions in food policies and ethnic conflicts may be offered. 


\section{NOTES}

1. Source: <https://www.un.org/millenniumgoals/>. Access:

28.11.2019.

2. Source: <www.nobelprize.org > Access: 09.10.2020.

3. Source: $<$ https://www.independent.co.uk/news/world/global-hunger-coronavirus-pandemic-united-nations-zero-hunger-2030-a9616186.html >. Access: 14.07.2020. 4. Source: <https://slate.com/news-and-politics/2019/09/starvation-war-crime-syria-yemen-icc.html>. Access: 14.06.2020.

5. Yet, some historians argue that the Famine was used by the British government against the Irish people. See: $<$ https://www.independent.ie/entertainment/books/was-the-famine-genocide-by-the-british-28954929.html>. Access: 5.10.2018.

6. MURPHY, B. Was the Famine Genocide by the British? Access: 01.06.2019. 7. Source: <https://themoscowtimes.com/articles/with-oleg-sentsovs-hunger-strike-history-repeats-62811>. Access: 16.09.2018.

8. Source: <https://www.kyivpost.com/ukraine-politics/oleg-sentsov-announces-end-of-hunger-strike.html>. Access: 5.10.2018.

9. Source: <https://112.ua/glavnye-novosti/rada-vydvinula-kandidaturu-sencova-na-soiskanie-nobelevskoy-premii-mira-462764.html >. Access: 18.09.2018.

10. Source: <https://www.bbc.co.uk/news/world-europe-17824709>. Access: 16.09.2018.

11. Source: <https://www.unian.info/politics/101135982-nadiia-savchenko-suspends-hunger.html>. Access: 16.09.2018.

12. Source: $<$ https://112.international/politics/ukrainian-political-prisoner-balukh-announces-hunger-strike-again-41151.html>. Access: 02.07.2019.

13. Source: <https://www.rferl.org/amp/ukraine-saakashvili-detained-kyiv-sbu-lutsenko/28905845.html?fbclid=IwAR1VujJOoLFc0pesh7p6KU8zvLsUPTWOOqBkF9AzlnNnmgccAVTMZpNRrNk>. Access: 21.04.2020. 14. Source: <https://www.kyivpost.com/article/content/ukraine-politics/lutsenko-ends-hunger-strike-105069.html?fbclid=IwAR3EvQSSg_yaKsbiq6GH4mSbq6SIyj8w5rYPQSPi5auI39OJ34OVH8CazFw>. Access: 21.04.2020.

15. Source: <https://www.unian.info/politics/amp-495309-tymoshenko-urges-yuriy-lutsenko-to-end-hunger-strike.html?fbclid=IwAR31oQJEZtpIEBAvREasXjFzdegc93kzDsYdau_8XhVDefNmSAwgl_TLmpM>. Access: 21.04.2020. 16. Source: $<$ http://khpg.org/en/index.php?id=1572035490>. Access: 14.06.2020. 17. Source: <https://uacrisis.org/en/74120-weekly-update-ukraine-37-18-24-november $>$. Access: 14.06.2020.

18. Source: <https://mettacenter.org/blog/revolution=-granite/?fbclidIwAR1u0M62lVbVetxWM827poLXDmPj_CaWaLOIGkUnim_N0DSbicXbnlx8aTw>. Access: 21.04.2020.

19. Source:<https://www.kyivpost.com/ukraine-politics/34-ukrainians-35-political-prisoners-24-pow-sailors-illegally-kept-in-crimea-and-russia.html?cn-reloaded=1>. Access: 02.07.2018.

20. I do not compare or decide who is a prisoner or terrorist, criminal or victim. I am talking about the mechanism of the criminalization of oppositional groups in the prison system.

21.Source:<https://jacobinmag.com/2020/05/

one-mans-terrorist-daniel-finn-review-ira?fbclid=IwAR2hAwVrWqi1M89sziuyT3wFpyT2qCAx221ua5jfG9tnkXMBMSetfFPlxaM>. Access: 22.05.2020. 22.Source:<https://jacobinmag.com/2020/05/

one-mans-terrorist-daniel-finn-review-ira?fbclid=IwAR2hAwVrWqi1M89sziuyT3wFpyT2qCAx221ua5jfG9tnkXMBMSetfFPlxaM>. Access: 22.05.2020. 


\section{REFERENCES}

ACHESON, Nicholas; MILOFSKY, Carl; STRINGER, Maurice. Understanding the role of non-aligned civil society in peacebuilding in Northern Ireland: Towards a Fresh Approach. In: POWER, Maria (ed.). Building peace in Northern Ireland. Liverpool: Liverpool University Press, 2011.

AGAMBEN, Giorgio. Homo sacer: sovereign power and bare life. Stanford University Press, Stanford 1998.

ANDERSON, Benedict. Imagined communities. London; New York: Verso, 1983.

APPLEBAUM, Ann. Red famine: Stalin's war on Ukraine. New York: Knopf Doubleday, 2018.

BAYER, Alexei. Ukraine is the Ireland of the Russian Empire. Source: <https://www.kyivpost.com/article/opinion/op-ed/alexei-bayer-ukraine-is-the-ireland-of-the-russian-empire.html>. Access: 16 may 2019.

BECK, Ulrich. Power in the Global Age. Cambridge: Polity Press, 2005.

BEIER J. Marshall; MUTIMER David. Pathologizing subjecthoods: pop culture, habits of thought, and the unmaking of resistance politics at Guantanamo Bay. International Political Sociology, n. 8, p. 311-323, 2014.

BNE SAAD, Majda. The global hunger crisis: tackling food insecurity in developing countries. London: Pluto Press, 2013.

BUTTERLY John R.; SHEPHERD J. Hunger: the biology and politics of starvation. Hanover; London: University Press of New England, 2010.

CARAMANI, Daniele. Comparative politics. Oxford: Oxford University Press, 2008.

CARR, Edward R. Postmodern conceptualizations, modernist applications: Rethinking the role of society in food security. Food policy, n. 31, p. 14-29, 2006.

CAVALCANI, Henrique B. Food Security. In: DODDS, Felix; PIPPARD, Tim. Humanitarian and environmental security. London: Routledge, 2005. CRIBB Julian. Food or war. Cambridge: Cambridge University Press, 2019.

EMERAN, Christine. New political activism in Ukraine: 2000-2014. London: Routledge, 2017.

ESPOSITO, Roberto. Bios: biopolitics and philosophy. Minneapolis; London: University of Minnesota Press, 2004.

GENEL, Katia. The question of biopower: Foucault and Agamben. Rethinking Marxism, v. 18, n. 1, p. 43-62, 2006.

GRIVIN, Brian. "Nationalism and the continuation of political conflict in Ireland". Proceedings of the British Academy, n. 98, p. 369-380, 1999.

HARVEY, David. The condition of postmodernity: an enquiry into the origins of cultural change. Oxford: Blackwell Publisher, 1989.

HAYWARD, Katy; McCALL, Cathal; DAMKAT, Ivo. Building peace and crossing borders: the North/South dimension of reconciliation. In: POWER, Maria (ed.). Building peace in Northern Ireland. Liverpool: Liverpool University Press, 2011. 
JACKSON Michlel. The politics of storytelling: variations on a theme by Hannah Arendt. Copenhagen: Museu Tusculanum Press, 2013.

JONES Reece. Violent borders: refugees and the right to move. London; New York: Verso, 2006.

KAPPELER, Andreas. Ukraine and Russia: legacies of the imperial past and competing memories. Journal of Eurasian Studies, n. 5, 2014.

KUZIO, Taras. Ukraine: state and nation building. London; New York: Routledge, 1998.

McEVOY, Kieran; SHIRLOW, Pete. Encumbered by data: understanding politically motivated prisoners and the transition to peace in Northern Ireland. In: POWER, Maria (ed.). Building Peace in Northern Ireland. Liverpool: Liverpool University Press, 2011.

McGLINCHEY, Marisa. Unfinished business: the politics of "dissent" Irish republicanism. Manchester: Manchester University Press, 2019.

McVEIGH, Robbie. Incitement to hatred in Northern Ireland. Equality Coalition, CAJ 2018.

MENKISZAK, Marek. Borders in flux: Ukraine as a case study of Russia's approach to its borders. Eurasia Border Review, v. 6, n. 1, p. 83-102, 2015.

MILIO, Nancy. Shaping food and nutrition policy in the new Europe. In: MILIO, Nancy; HELSING, Elisabet (ed.). European food and nutrition policies in action. WHO Regional Publications, European Series, n. 73, 1998.

MULHOLLAND, Marc. Northern Ireland: a very short introduction. Oxford: Oxford University Press, 2002.

MULORE, Patrick. Bombs, bullets and the border. Policing Ireland's frontier: Irish security policy 1969-78. Newbridge: Irish Academy Press, 2017.

NOACK, Christian; JANSSEN, Lindsay; COMERFORD, Vincent. Holodomor and Gorta Mór: histories, memories and representations of famine in Ukraine and Ireland. Cambridge: Anthem Press, 2013.

PRINCE, Simon. Northern Ireland's '68: civil rights, global revolt and the origins of the Troubles. Newbridge: Irish Academic Press, 2018.

PRONK, Jan. Globalization, poverty and security. In: DODDS, Felix; PIPPARD, Tim. Humanitarian and environmental security. London: Routledge, 2005.

SCOTT, James W. A research agenda for border studies. Blackwell's: Edward Elgar Publishing, 2020.

SWEENEY, George. Hunger strikes and the political confrontation. Anthropology Today, v. 9, n. 5, 1993.

UNICEF. Global framework for action: ending child hunger and undernutrition initiative. 2006.

WOLOWYNA, Oleh; PLOKHY, Serhii; LEVCHUK, Nataliia; RUDNYTSKYI, Omelian; KOVBASIUK, Alla; SHEVCHUK, Pavlo. Regional variations of 1932-34 famine losses in Ukraine. Canadian studies in population, v. 43, n. 3-4, p. 172-202, 2016. 